\title{
Fatal attractions: abnormal protein aggregation and neuron death in Parkinson's disease and Lewy body dementia
}

\author{
John Q. Trojanowski ${ }^{1,4}$, Michel Goedert ${ }^{2}$, Takeshi Iwatsubo ${ }^{3}$ \\ and Virginia M.-Y. Lee ${ }^{1}$ \\ 1 The Center for Neurodegenerative Disease Research, Department of Pathology \\ and Laboratory Medicine, University of Pennsylvania School of Medicine, \\ Philadelphia, PA, USA \\ 2 The MRC Laboratory of Molecular Biology, Hills Road, Cambridge, UK \\ ${ }^{3}$ The Department of Neuropathology and Neuroscience, Graduate School of \\ Pharmaceutical Sciences, University of Tokyo, Tokyo, Japan \\ ${ }^{4}$ corresponding author: John Q. Trojanowski, Center for Neurodegenerative \\ Disease Research, Department of Pathology and Laboratory Medicine, \\ University of Pennsylvania School of Medicine, HUP, Maloney Building, 3rd \\ Floor, Philadelphia, PA 19104-4283, USA. tel: 215-662-6399; fax: 215-349- \\ 5909; \\ e-mail: trojanow@mail.med.upenn.edu
}

Received 12.2.98; revised 3.6.98; accepted 23.6.98

Edited by G. Melino

\begin{abstract}
The abnormal aggregation of proteins into fibrillar lesions is a neuropathological hallmark of several sporadic and hereditary neurodegenerative diseases. For example, Lewy bodies (LBs) are intracytoplasmic filamentous inclusions that accumulate primarily in subcortical neurons of patients with Parkinson's disease (PD), or predominantly in neocortical neurons in a subtype of Alzheimer's disease (AD) known as the LB variant of $A D$ (LBVAD) and in dementia with LBs (DLB). Aggregated neurofilament subunits and $\alpha$-synuclein are major protein components of LBs, and these inclusions may contribute mechanistically to the degeneration of neurons in PD, DLB and LBVAD. Here we review recent studies of the protein building blocks of LBs, as well as the role LBs play in the onset and progression of PD, DLB and LBVAD. Increased understanding of the protein composition and pathological significance of LBs may provide insight into mechanisms of neuron dysfunction and death in other neurodegenerative disorders characterized by brain lesions containing massive deposits of proteinacious fibrils.
\end{abstract}

Keywords: Lewy bodies; dementia; neurofilaments; Parkinson's disease; synuclein

Abbreviations: $\mathrm{A} \beta, \beta$-amyloid peptide; $\mathrm{AD}, \mathrm{Alzheimer's} \mathrm{disease;}$ DLB, dementia with Lewy bodies; FAD, familial AD; GOls, glial cell inclusions; LBs, Lewy bodies; LBVAD, LB variant of AD; MAbs, monoclonal antibodies; MSA, multiple system atrophy; NAC, nonA $\beta$ component; NACP, NAC precursor protein; NF, neurofilaments; NFTs, neurofibrillary tangles; PNP14, phosphoneuronoprotein 14; SPs, senile plaques
Abnormal protein-protein interactions that result in the formation of intracellular and extracellular aggregates of proteinacious fibrils are a common neuropathological feature of several different sporadic and hereditary neurodegenerative diseases (for recent reviews, see Goedert et al, 1997; Lansbury, 1997; Tu et al, 1997a; Trojanowski et al, 1998). This is exemplified by the intranuclear neuronal inclusions that are formed by the aggregation of mutant proteins harboring abnormally expanded polyglutamine tracts in hereditary trinucleotide repeat disorders, the intracytoplasmic neurofibrillary tangles (NFTs) as well as the extracellular amyloid plaques in sporadic and familial Alzheimer's disease (AD), and by the prion protein deposits in the brains of patients with a sporadic or genetic form of spongiform encephalopathy. Indeed, increasing evidence (see for example Pollanen et al, 1993b; Goedert et al, 1997; Lansbury, 1997; Tompkins et al, 1997; Tu et al, 1997a, b; Igarashi et al, 1998; Martindale et al, 1998; Poorkaj et al, 1998; Trojanowski et al, 1998; Vogel, 1998) suggests that abnormal protein-protein interactions and/or the lesions that result from the aggregation of these proteins could play a mechanistic role in the dysfunction and death of neurons in several common neurodegenerative diseases (see Table 1).

Although Lewy bodies (LBs) are regarded as hallmark intracytoplasmic neuronal inclusions of Parkinson's disease (PD), they also occur commonly in the brains of patients with the typical clinical and pathological features of $A D$, and these cases are designated as the $L B$ variant of $A D$ (LBVAD) (for reviews, see Pollanen et al, 1993b; McKeith et al, 1996; Hansen and Samuel, 1997; Trojanowski et al, 1998). Further, numerous cortical LBs are the defining brain lesions of a neurodegenerative disorder known as dementia with LBs (DLB), which is similar to AD clinically, but distinct from $A D$ pathologically because NFTs and senile plaques (SPs) are rare or completely absent in DLB brains (Pollanen et al, 1993b; McKeith et al, 1996; Hansen and Samuel, 1997; Trojanowski et al, 1998). Thus, LBVAD also may reflect the co-occurrence of $A D$ and DLB in the same patient. LBs contain masses of $7-25 \mathrm{~nm}$ in diameter filaments that appear similar to neurofilaments (NFs) by electron microscopy, but the precise molecular composition of LBs is unclear, and their role in the degeneration of neurons in PD, DLB and LBVAD.

Recent reports of familial PD kindreds with mis-sense mutations in the $\alpha$-synuclein gene (Polymeropoulos et al, 1997; Kruger et al, 1998), as well as the demonstration that $\alpha$-synuclein, but not $\beta$-synuclein, is a major component of LBs in sporadic PD, DLB and the LB variant of AD (Spillantini et al, 1997b; Wakabayashi et al, 1997; Baba et al, 1998; Irizarry et al, 1998; Takeda et al, 1998) open up new avenues of research on these disorders. 
Table 1 Neurodegenerative diseases characterized by filamentous lesions formed from aggregated peptides/proteins

\begin{tabular}{|c|c|c|}
\hline Disease & Lesion/components & Location \\
\hline$A D^{*}$ & $\begin{array}{l}\mathrm{SPs} / \mathrm{A} \beta, \mathrm{NAC} \\
\text { NFTs/PHTtau }\end{array}$ & $\begin{array}{l}\text { Extracellular } \\
\text { Intracytoplasmic }\end{array}$ \\
\hline $\begin{array}{l}\text { Amyotrophic lateral } \\
\text { sclerosis }\end{array}$ & Spheroids/NF subunits & Intracytoplasmic \\
\hline DLB\# & $\begin{array}{l}\text { LBs/NF subunits, } \\
\alpha \text {-synuclein }\end{array}$ & Intracytoplasmic \\
\hline LBVAD (AD+DLB)\# & $\begin{array}{l}\mathrm{SPs} / \mathrm{A} \beta, \text { NAC } \\
\text { NFTs/PHFtau } \\
\text { LBs/NF subunits, } \\
\alpha \text {-synuclein }\end{array}$ & $\begin{array}{l}\text { Extracellular } \\
\text { Intracytoplasmic } \\
\text { Intracytoplasmic }\end{array}$ \\
\hline MSA\# & GCls/ $\alpha$-synuclein & Intracytoplasmic \\
\hline $\begin{array}{l}\text { Neuronal intranuclear } \\
\text { inclusion disease }\end{array}$ & $\begin{array}{l}\text { Inclusions/expanded } \\
\text { polyglutamine tracts }\end{array}$ & Intranuclear \\
\hline PD\# & $\begin{array}{l}\text { LBs/NF subunits, } \\
\alpha \text {-synuclein }\end{array}$ & Intracytoplasmic \\
\hline Prion diseases & Amyloid plaques/prions & Extracellular \\
\hline Tauopathies* & NFTs/AD-like PHFtau & Intracytoplasmic \\
\hline $\begin{array}{l}\text { Tri-nucleotide repeat } \\
\text { diseases }\end{array}$ & $\begin{array}{l}\text { Inclusions/expanded } \\
\text { polyglutamine tracts }\end{array}$ & Intranuclear \\
\hline
\end{tabular}

This table summarizes hereditary and sporadic neurodegenerative disorders characterized by distinct filamentous brain lesions that accumulate in the extracellular space or within cells (e.g. neurons, glial cells). The dominant structural components of these lesions are indicated. ${ }^{*} A D$ is a heterogeneous dementing disorder that includes several variants (i.e. sporadic $A D, F A D$, LBVAD, tangle predominant AD), but they partially overlap with the tauopathies, a diverse group of sporadic and hereditary neurodegenerative diseases that share similar neuropathological abnormalities, i.e. intracytoplasmic inclusions (in neurons and/or glial cells) composed of hyperphosphorylated tau proteins incorporated into abnormal filaments (Goedert et al, 1997; Spillantini et al, 1997a). Some well characterized 'tauopathies' are: progressive supranuclear palsy, Pick's disease, corticobasal degeneration, familial frontotemporal dementia and parkinsonism linked to chromosome 17 (FTDP-17) and Guam amyotrophic lateral sclerosis/parkinsonism dementia complex. Although the mechanisms leading to tau pathology in these disorders are poorly understood, pathogenic missense mutations in exons and introns of the tau gene have been detected in autosomal dominantly inherited FTDP-17 (Hutton et al., 1998; Poorkaj et al, 1998; Vogel, 1998). \#Increasing insights into the role $\alpha$-synuclein plays in these disorders may result in a reclassification of these diseases as different types of ' $\alpha$-synuclein proteinpathies'

Indeed, these reports are likely to stimulate more extensive studies of the abnormal protein-protein interactions that result in the formation of LBs as well as a reassessment of the role LBs play in the pathogenesis of these disorders (Chase, 1997; Goedert, 1997; Heintz and Zoghbi, 1997; Lansbury, 1997). Since the mutations described in familial PD lead to an Ala to Thr substitution at position 53 (A53T) or an Ala to Pro substitution at position $30(\mathrm{~A} 30 \mathrm{P})$ in the $\alpha$-synuclein protein, these mutations could alter the biophysical properties of $\alpha$ synuclein, a poorly understood protein that is expressed primarily in neurons where it is localized predominantly at axon terminals or synapses.

Synuclein was identififed initialy in Torpedo electroplaques (Maroteaux et al, 1988), and in the rat brain (Maroteaux and Scheller, 1991). Subsequently, a fragment of the 140 amino acid long human $\alpha$-synuclein protein was reported to be present in some amyloid plaques of $A D$ brains (Ueda et al, 1993), and follow up studies suggested that this peptide or its precursor might contribute to the fibrillogenesis of the $\beta$-amyloid peptide $(\mathrm{A} \beta)$ in SPs (Yoshimoto et al, 1995; Weinreb et al, 1996; Jensen et al, 1997). This peptide fragment of human $\alpha$-synuclein was designated the non-A $\beta$ component (NAC) of amyloid plaques while the precursor protein of the NAC peptide was called NACP (Ueda et al, 1993; Iwai et al, 1995). Human $\beta$-synuclein also was identified, and it is a 134 amino acid long protein with homologies to human $\alpha$-synuclein (Jakes et al, 1994; Goedert, 1997). However, human $\alpha$ - and $\beta$-synucleins are encoded by different genes located on chromosomes 4 (4q21) and 5 (5q35), respectively (Campion et al, 1995; Chen et al, 1995; Shibashi et al, 1995; Spillantini et al, 1995). Further, the bovine homologue of human $\beta$-synuclein has been characterized and it is known as phosphoneuronoprotein 14 or PNP14 (Nakajo et al, 1990; 1993; 1996; Shibayama-Imazu et al, 1993), while the song bird homologue of human synuclein is known as synelfin, and anti-synelfin antibodies crossreact with mammalian synucleins (George et al, 1995; Irizarry et al, 1996; Withers et al, 1997). Although the existence of other synuclein-like proteins has been reported, the cellular and regional distribution of these polypeptides in the brain has not been well characterized (Akopian et al, 1995; Ji et al, 1997).

Despite uncertainties about the normal function of $\alpha$ synuclein in neurons, the A53T and A30P mutations in human $\alpha$-synuclein appear to be the cause of familial PD in a small subset of known kindreds with this hereditary disorder (Polymeropoulos et al, 1997; Kruger et al, 1998). Thus, it is reasonable to speculate that these mis-sense mutations may predispose the normally soluble and randomly structured $\alpha$-synuclein protein to aggregate or interact aberrantly with itself or other proteins (e.g. NF subunits) leading to the formation of filaments that aggregate into LBs and contribute to the degeneration of affected neurons in familial PD.

The recent reports of the widespread presence of $\alpha$ synuclein in perikaryal LBs and in dystrophic neuronal processes of the brains of patients with sporadic PD, DLB and LBVAD is highly significant for understanding the pathogenesis of these disorders because this finding implies that wild-type $\alpha$-synuclein also may aggregate by itself or with other proteins into LBs and dystrophic neurites even in the absence of a mutation (Spillantini et al, 1997b; 1998; Wakabayashi et al, 1997; Baba et al, 1998; Irizarry et al, 1998; Takeda et al, 1998). Indeed, recent immunohistochemical studies indicate that antibodies to $\alpha$-synuclein reveal a much more extensive network of dystrophic processes (so-called 'Lewy neurites') in the brains of patients with sporadic DLB, PD and LBVAD than had been demonstrated previously with antibodies to NF proteins or other polypeptides contained within LBs (for example, see Goldman et al, 1983; Dickson et al, 1991; 1994; Hill et al, 1991; Schmidt et al, 1991; 1996; Pollanen et al, 1993b; Iwatsubo et al, 1996; Galvin et al, 1997; Trojanowski et al, 1998). These Lewy neurites were reported first in the CA2/3 region of the hippocampus, and this novel neuritic pathology appeared to be restricted to LB disorders (Dickson et al, 1991). A subsequent immunohistochemical study demonstrated extensive similarities between the profile of immunodetectable polypeptides in LBs and Lewy neurites suggesting that both lesions result from a common pathogenic mechanism (Dickson et al, 1994). 
However, filamentous inclusions with abundant $\alpha$ synuclein immunoreactivity are not restricted to classic LB diseases such as PD, DLB and LBVAD. For example, the postmortem brains of individuals with familial $A D$ (EAD) due to autosomal dominant mutations in the Presenilin 1, Presenilin 2 or the $\mathrm{A} \beta$ precursor protein genes contain variable numbers of $\alpha$-synuclein positive LBs, especially in the amygdala (Lippa et al, 1998). Notably, LBs also are abundant in the amygdala of patients with sporadic AD (Schmidt et al, 1996). Surprisingly, $\alpha$-synuclein also is a major component of the filamentous glial cell inclusions (GCls) that are abundant in the white matter oligodendroglial cells of multiple system atrophy (MSA) brains, and these white matter GCls are diagnostic hallmarks of this complex of syndromes which is comprised of a small group of rare but similar neurodegenerative movement disorders (Tu et al, 1998). Thus, the accumulation of $\alpha$-synuclein into filamentous inclusions could play a mechanistic role in the pathogenesis of a number of progressive neurological disorders in addition to PD, DLB, FAD, LBVAD, sporadic $A D$ and MSA.

The mechanisms that might account for the accumulation of $\alpha$-synuclein into filamentous inclusions in sporadic neurodegenerative diseases remain to be determined, but it is possible that genetic risk factors as well as epigenetic events could perturb the metabolism or solubility of $\alpha$-synuclein, or influence the interactions of $\alpha$-synuclein with itself as well as with other neuronal proteins in disorders such as PD and DLB. As a consequence thereof, $\alpha$-synuclein could accumulate in Lewy neurites or as filamentous aggregates in perikaryal LBs. Further, it is plausible that these lesions could compromise the survival of affected neurons in these nonhereditary LB disorders. Thus, in addition to expanded polyglutamine tracts, NF proteins, prions, tau and $\mathrm{A} \beta$ (Goedert et al, 1997; Lansbury, 1997; Tu et al, 1997a; Lieberman et al, 1998; Poorkaj et al, 1998; Trojanowski et al, 1998; Vogel, 1998), $\alpha$-synuclein now has entered the research arena as player in the formation of fibrillar brain lesions that may result from abnormal protein-protein interactions in sporadic and hereditary neurodegenerative diseases.

Until recently, most of the major insights into the composition of LBs have come from reports on immunohistochemical studies of LBs published over the past 15 years (for reviews, see Pollanen et al, 1993b; Trojanowski et al, 1998). For example, NF subunits were among the first neuronal proteins detected in LBs of the PD brain (Goldman et al, 1983). Since NFs are the major class of intermediate filaments in neurons and they are heteropolymers of three distinct subunit proteins, these initial findings were extended in subsequent immunihistochemical epitope mapping studies of LBs (Hill et al, 1991; Schmidt et al, 1991). Briefly, using a large library of $>300$ monoclonal antibodies (MABs) specific for defined protein domains in each of the three NF subunits, it was shown that cortical and subcortical LBs share a similar profile of NF protein epitopes, and that the topographical distribution of these epitopes spanned nearly the entire extent of each of the three NF subunits. Thus, these studies provided indirect evidence suggesting that very large segments of each of the NF triplet proteins were incorporated into LBs.

Although antibodies to ubiquitin label more LBs than antibodies to NF subunits, many different lesions within and outside the brain (e.g. NFTs, SPs, Rosenthal fibers, Mallory bodies, Pick bodies, etc.) are labeled by anti-ubiquitin antibodies (Pollanen et al, 1993b; Trojanowski et al, 1998). This may be explained by the fact that many abnormal proteins are targeted for degradation by ubiquitination, a process whereby ubiquitin (a 76 amino acid long protein) is conjugated through an isopeptide bond between its carboxy terminal glycine and the $\varepsilon$-amino group of lysine in the protein that is being targeted for degradation. Thus, the detection of ubiquitin immunoreactivity in a lesion probably reflects the activation of the ubiquitin pathway to eliminate damaged proteins in a degenerating neuron. Accordingly, ubiquitin positivity is not specific for LBs.

While considerable attention has been focused on research into the role of NF proteins and ubiquitin in the pathogenesis of LBs, a large number of other neuronal proteins also have been detected in LBs by immunohistochemistry (Pollanen et al, 1993b; Trojanowski et al, 1998). However, it is likely that many proteins become trapped non-specifically in the mesh of filaments that aggregate into LBs, but these proteins are not essential LB components. Nonetheless, some of these proteins may play a significant role in the formation of LBs even though they are not structural elements of LB filaments. For example, accessory proteins could function as pathological chaperones or co-factors at different stages in the formation of LBs by promoting abnormal protein-protein interactions, augmenting fibrillogenesis or facilitating the progressive aggregation of abnormal filaments into increasingly large inclusions that eventually become recognizable as LBs.

To gain further insight into the pathobiology of LBs, methods for the purification of these inclusions from the postmortem brains of patients with LBs disorders were developed, and this has enabled the generation of MABs to LB proteins. The initial efforts to purify LBs provided evidence which supported the findings from earlier immunohistochemical studies suggesting that NF proteins are present in LBs (Pollanen et al, 1992; 1993a; 1994). Consistent with these results, subsequent studies designed to generate MAbs specific for proteins in purified LBs also demonstrated the presence of NF subunits and ubiquitin in LBs (Iwatsubo et al, 1996; Galvin et al, 1997). More recently, an MAb (LB509) raised to LBs purified from DLB cortex was shown to specifically recognize human $\alpha$ synuclein (Baba et al, 1998). Significantly, the LB509 MAb strongly labeled numerous cortical as well as subcortical LBs and dystrophic Lewy neurites, and it also decorated LB filaments in immuno-electron microscopic studies. Further, LB509 detected normal, partially degraded as well as aggregated forms of $\alpha$-synuclein in Western blots of highly purified LBs. Thus, these data provide compelling evidence that $\alpha$-synuclein is a major structural component of LBs and the dystrophic Lewy neurites in sporadic PD, DLB and LBVAD. 
Additional MAbs raised to purified LBs like LB509 should facilitate efforts to elucidate the biochemical composition of these neuronal inclusions, and this information could be exploited to determine how LBs form, and whether or not they contribute to the degeneration of affected neurons in LB disorders. Further, anti-LB MAbs could be used to develop assays for the early antemortem diagnosis of LB disorders by monitoring the levels of LB proteins in blood, urine, cerebrospinal fluid or other bodily fluids in patients and controls. Although information on the biological consequences of LB formation is incomplete, studies of human LB disorders and transgenic mice that develop NF rich LB-like abnormalities support the notion that these filamentous inclusions could lead to the death of affected neurons (Tu et al, 1997a; b; Trojanowski et al, 1998). However, the refinement and use of methods for the purification and analysis of LBs isolated from postmortem brain tissue should accelerate efforts to dissect the building blocks of LB filaments and to identify other components that contribute to the formation of LBs.

Further understanding of the biological significance of LBs in patients with PD or DLB should emerge more quickly now as the pace of research on these inclusions accelerates. This is especially important following the discovery that $\alpha$-synuclein is mutated in familial PD (Polymeropoulos et al, 1997; Kruger et al, 1998), and that wild-type $\alpha$-synuclein is a major component of LBs in sporadic PD, DLB and LBVAD (Spillantini et al, 1997b; Wakabayashi et al, 1997; Baba et al, 1998; Irizarry et al, 1998; Takeda et al, 1998), including the abnormal filaments that dominate the ultrastructural images of LBs (Baba et al, 1998). For example, future studies should seek to determine how: (1) Aberrant protein-protein interactions between $\alpha$-synuclein and itself, or with NFs and other neuronal proteins lead to the abnormal accumulation of these proteins into pathological LBs in PD, DLB and LBVAD; (2) Mutations in FAD genes lead to LB formation in the brains of affected members of these kindreds; (3) Fragments of $\alpha$-synuclein (i.e. NAC) contribute to amyloidogenesis in AD; (4) $\alpha$-synuclein, a predominantly neuronal protein, accumulates into the filamentous $\mathrm{GCls}$ of white matter oligodendroglia of MSA.

Equally important are additional studies to determine whether or not LBs compromise the function and viability of neurons in PD, DLB and LBVAD. For example, studies of several animal models of motor neuron disease in which the accumulation of NF-rich perikaryal inclusions precedes the degeneration of affected motor neurons ( $\mathrm{Tu}$ et al, 1997a), as well as studies of a transgenic mouse model in which LB-like inclusions compromise the long term survival of a subset of affected neurons (Tu et al, 1997b) suggest the possibility that LBs play a mechanistic role in the degeneration of neurons. Indeed, there is evidence that LB containing neurons may undergo apoptosis in the PD brain (Tompkins et al, 1997), and that the burden of LBs in neocortex correlates with dementia (Samuel et al, 1996). While these observations need to be extended, the demonstration that expanded polyglutamine tracts form filamentous inclusions which induce apoptotic cell death lends credence to the notion that apoptosis could be a consequence of these distinctive intracellular lesions (Igarashi et al, 1998; Martindale et al, 1998). However, as summarized in other reviews here (Friedlander and Yuan, 1998; Sadoul, 1998), it is becoming increasingly evident that the mechanisms underlying apoptotic cell death in the nervous system are highly complex, and that apoptosis may contribute to the massive loss of neurons in a number of different neurodegenerative disorders.

If LBs and/or dystrophic Lewy neurites are proven to compromise the long term survival of at least some affected neurons, it is important to realize that these lesions could have a deleterious effect on the function of neurons even if they do not degenerate completely and disappear. For example, the axons of LB-containing nigral and cortical neurons might undergo a 'dying back' process due to: (1) A disruption of perikaryal transport mechanisms by LBs that form in neuronal cell bodies; (2) A blockage of axonal transport by proteins that aggregate in the plethora of dystrophic Lewy neurites that are detected by immunohistochemistry using antibodies to $\alpha$-synuclein. Thus, these pathological events could lead to the degeneration of the axons and/or dendrites of the affected neurons even if the cell bodies of these neurons somehow survive for some period of time after they acquire a LB. Significantly, this could lead to a functional or physical disconnection of neuronal circuits (e.g. those linking the substantia nigra with the striatum or one cortical region with another) in the brains of patients with PD, DLB and LBVAD. Obviously, the development of transgenic mouse models of LBs based on the over expression of wild-type or mutant human $\alpha$ synuclein should facilitate studies to determine if LBs have deleterious consequences on the health or long term viability and function of affected neurons and their processes.

Accordingly, a resurgence in efforts to elucidate the pathobiology of LBs may lead to improved strategies for the antemortem diagnosis and treatment of PD, DLB and the variant of $A D$ that is associated with abundant cortical LBs. Equally significant, further insights into these issues could clarify mechanisms of neuronal and glial pathology in other neurodegenerative diseases characterized by brain lesions formed from aggregates of proteinacious filaments (see Table 1). Indeed, the aggregation of brain proteins into potentially toxic lesions (hence the reference to 'fatal attractions' in the title of this review) is emerging as a common mechanistic theme in a diverse group of neurodegenerative diseases that share an enigmatic symmetry, i.e. mis-sense mutations in the gene encoding the disease protein cause a familial variant of the disorder as well as its hallmark brain lesions, but the same brain lesions also can be formed by the corresponding wild-type protein in a sporadic form of the disease (Goedert et al, 1997; Lansbury, 1997; Tu et al, 1997a; Lieberman et al, 1998; Poorkaj et al, 1998; Trojanowski et al. 1998; Vogel, 1998). Thus, it is likely that clarification of this enigmatic symmetry in any one of these disorders will have a profound impact on understanding the mechanisms that underlie all of these disorders as well as on efforts to develop novel therapies to treat them. 


\section{Acknowledgements}

Portions of the work reviewed here were supported by grants from National Institute on Aging and the National Institute of Neurological Disorders and Stroke of the National Institutes of Health.

\section{References}

Akopian AN and Wood JN (1995) Peripheral nervous system-specific genes identififed by subtractive cDNA cloning. J. Biol. Chem. 36: 21264-21270

Baba M, Nakajo S, Tu P-H, Tomita T, Nakaya K, Lee VM-Y, Trojanowski JQ and Iwatsubo T (1998) Aggregation of $\alpha$-synuclein in Lewy bodies of sporadic Parkinson's disease and dementia with Lewy bodies. Am. J. Pathol. 152: 879 884

Campion D, Martin C, Heilig R, Charbonnier F, Moreau V, Flaman JM, Petit JL, Hannequin D, Brice A and Frebourg T (1995) The NACP/synuclein gene: Chromosomal assignment and screening for alterations in Alzheimer's disease. Genomics 26: 254-257

Chase TN (1997) A gene for Parkinson disease. Arch. Neurol. 54: 1156-1157

Chen X, Rohan de Silva HA, Pettenati MJ, Rao PN, St George-Hyslop R, Roses AD, Xia Y, Horsburgh K, Ueda K and Saitoh T (1995) The human NACP/alphasynuclein gene: Chromosomal assignment to 4q21.3-q22 and Taql RFLP analysis. Genomics 26: 425-427

Dickson DW, Ruan D, Crystal H, Mark MH, Davies P, Kress Y and Yen S-H (1991) Hippocampal degeneration differentiates diffuse Lewy body disease (DLBD) from Alzheimer's disease: Light and electron microscopic immunocytochemistry of CA2-3 neurites specific to DLBD. Neurol. 41: 1402-1409

Dickson DW, Schmidt ML, Lee VM-Y, Zhao ML, Yen S-H and Trojanowski JQ (1994) Immunoreactivity profile of hippocampal CA2/3 neurites in diffuse Lewy body disease. Acta Neuropathol. 87: 269-276

Friedlander RM and Yuan J (1998) ICE, neuronal apoptosis and neurodegeneration. Cell Death Differ 5: 823-831

Galvin JE, Lee VMY, Baba M, Mann DMA, Dickson DW, Yamagushi H, Schmidt ML, Iwatsubo T and Trojanowski JQ (1997) Monoclonal antibodies to purified cortical Lewy bodies recognize the midsize neurofilament subunit. Ann. Neurol. 42 $595-603$

George JM, Jin H, Woods WS and Clayton DF (1995) Characterization of a novel protein regulated during the critical period for song learning in the zebra finch. Neuron 15: 361-372

Goedert M (1997) The awakening of $\alpha$-synuclein. Nature 388: 232-233

Goedert M, Trojanowski JQ and Lee VM-Y (1997) The neurofibrillary pathology of Alzheimer's disease. In The Molecular and Genetic Basis of Neurological Disease, 2nd Edition, Prusiner SB, Rosenberg RN, Di Mauro S and Barchi RL (eds). pp. 613-627, Boston, MA, Butterworth Heineman Press

Goldman JE, Yen SH, Chiu FC and Peress NS (1983) Lewy bodies of Parkinson's disease contain neurofilament antigens. Science 221: 1082-1084

Hansen LA and Samuel W (1997) Criteria for Alzheimer's disease and the nosology of dementia with Lewy bodies. Neurol. 48: 126-132

Heintz N and Zoghbi H (1997) Alpha-synuclein - A link between Parkinson and Alzheimer diseases? Nature Genetics 16: 325-327

Hill WD, Lee VMY, Hurtig HI, Murray JM and Trojanowski JQ(1991) Epitopes located in spatially separate domains of each neurofilament subunit are present in the Lewy bodies of Parkinson's disease. J. Comp. Neurol. 109: 150-160

Hutton M, Lendon CL, Rizzu P, Baker M, Froelich S, Houlden H, Pickering-Brown S, Chakraverty S, Isaacs A, Grover A, Hackett J, Adamson J, Lincoln S, Dickson D, Davies P, Petersen RC, Stevens M, de Graaff E, Wauters E, van Baren J, Hillebrain M, Joosse M, Kwon JM, Nowotny P, Che LK, Norton J, Morris JC, Reed LA, Trojanowski JQ, Basun H, Lannfelt L, Neystat M, Fahn S, Dark F, Tannenberg T, Dodd P, Hayward N, Snowden J, Craufurd D, Neary D, Owen F, Oostra B, Hardy J, Goate A, van Swieten J, Mann D, Lynch T and Heutnink P (1998) Coding and $5^{\prime}$ splice site mutation in Tau associated with inherited dementia (FTDP-17) Nature 393: 702-705

Igarashi S, Koide R, Shimohata T, Yamada M, Hayashi Y, Takano H, Date H, Oyake M, Sato T, Sato A, Egawa S, Ikeuchi T, Tanaka H, Nakano R, Tanaka K, Hozumi I, Inuzuka T, Takahashi H and Tsuji S (1998) Suppression of agregate formation and apoptosis by transglutaminase inhibitors in cells expressing truncated DRPLA protein with an expanded polyglutamine stretch. Nature Genetics 18 $111-117$
Irizarry MC, Growdon W, Gomez-Isla T, Newell K, George JM, Clayton DF and Hyman BT (1998) Nigral and cortical Lewy bodies and dystrophic nigral neurites in Parkinson's disease and cortical Lewy body disease contain $\alpha$-synuclein. J. Neuropath. Exper. Neurol. 57: 334-337

Irizarry MC, Kim T-W, McNamara M, Tanzi RE, George JM, Clayton DF and Hyman BT (1996) Characterization of the precursor protein of the non-A $\beta$ component of senile plaques (NACP) in the human central nervous system. J. Neuropath. Exper. Neurol. 55: 889-895

Iwai A, Masliah E, Yoshimoto M, Ge N, Flanagan L, de Silva HA, Kittel A and Saitoh T (1995) The precursor protein of non-A $\beta$ component of Alzheimer's disease amyloid is a presynaptic protein of the central nervous system. Neuron 14:467475

Iwatsubo T, Yamaguchi H, Fujimuro M, Yokosaww H, Ihara Y, Trojanowski JQ and Lee VM-Y (1996) Purification and characterization of Lewy bodies from the brains of patients with diffuse Lewy body disease. Am. J. Pathol. 148: 1517-1529

Jakes R, Spillantini MG and Goedert M (1994) Identification of two distinct synucleins from human brain. FEBS Lett. 345: 27-32

Jensen $\mathrm{PH}, \mathrm{Hoj}$ rup P, Hager H, Nielsen MS, Jacobsen L, Olesen OF, Gliemann J and Jakes $\mathrm{R}$ (1997) Binding of $\mathrm{A} \beta$ to $\alpha$ - and $\beta$-synucleins: identification of segments in $\alpha$-synuclein/NAC precursor that bind A $\beta$ and NAC. Biochem. J. 32: 539-546

Ji H, Liu YE, Jia T, Wang M, Liu J, Xiao G, Joseph BK, Rosen C and Shi YE (1997) Identification of a breast cancer-specific gene, BCSG1, by direct differential cDNA sequencing. Cancer Res. 57: 759-764

Kruger R, Kuhn W, Muller T, Woitalla D, Graeber M, Kosel S, Przuntek H, Epplen JT, Schols L and Riess O (1998) Ala30-to-pro mutation in the gene encoding alphasynuclein in Parkinson's disease. Nature Genetics 18: 106-108

Lansbury PT (1997) Structural neurology: Are seeds at the root of neuronal degeneration. Neuron 19: 1151-1154

Lieberman AP, Robitaille Y, Trojanowski JQ, Dickson DW and Fischbeck KH (1998) Polyglutamine-containing aggregates in neuronal intranuclear inclusion disease. Lancet 351: 884

Lippa CF, Fujiwara H, Mann DMA, Giasson D, Baba M, Schmidt ML, Nee LE, O'Connell B, Pollen DA, George-Hyslop PSt, Ghetti B, Nochlin D, Bird TD, Cairns NJ, Lee VM-Y, Iwatsubo T and Trojanowski JQ (1998) Lewy bodies contain altered $\alpha$-synuclein in brains of many familial Alzheimer's disease patients with mutations in presenilin and amyloid precursor protein genes. Am. J. Pathol. In press

Maroteaux L, Campanelli JT and Scheller RH (1998) Synuclein: A neuron-specific protein localized to the nucleus and presynaptic nerve terminal. J. Neurosci. 8: 2804-2815

Maroteaux L and Scheller RH (1991) The rat brain synuclein: Family of proteins transiently associated with neuronal membrane. Mol. Brain Res. 11: 335-343

Martindale D, Hackam A, Wieczorek A, Ellerby L, Wellington C, McCutcheon K, Singaraja R, Kazemi-Esfarjani P, Devon R, Kim SU, Bredesen DE, Tufaro F and Hayden MR (1998) Length of huntingtin and its polyglutamine tract influences localization and frequency of intracellular aggregates. Nature Genetics 18: 150 154

McKeith IG, Galasko D, Kosaka K, Perry EK, Dickson DW, Hansen LA, Salmon DP, Lowe J, Mirra SS, Byrne EJ, Lennox G, Quinn NP, Edwardson JA, Ince PG, Bergeron C, Burns A, Miller BL, Lovestone S, Collerton D, Jansen EN, Ballard C, de Vos RA, Wilcock GK, Jellinger KA and Perry RH (1996) Consensus guidelines for the clinical and pathologic diagnosis of dementia with Lewy bodies (DLB): Report of the consortium on DLB international workshop. Neurol. 47: 11131124

Nakajo S, Omata K, Aiuchi T, Shibayama T, Okahashi I, Ochiai H, Nakai Y, Nakaya K and Nakamura Y (1990) Purification and characterization of a novel brainspecific 14-kDa protein. J. Neurochem. 55: 2031-2038

Nakajo S, Tsukuda K, Kameyama H, Furuyama Y and Nakaya K(1996) Distribution of phosphoneuroprotein 14 (PNP 14) in vertebrates: Its levels as determined by enzyme immunoassay. Brain Res. 741: 180-184

Nakajo S, Tsukada K, Omata K, Nakamura Y and Nakaya K (1993) A new brainspecific $14-\mathrm{kDa}$ protein is a phosphoprotein. Its complete amino acid sequence and evidence for phosphorylation. Eur. J. Biochem. 217: 1057-1063

Pollanen MS, Bergeron C and Weyer L (1992) Detergent-insoluble cortical Lewy body fibrils share epitopes with neurofilament and tau. J. Neurochem. 58: 19531956

Pollanen MS, Bergeron C and Weyer L (1993a) Deposition of detergent-resistant neurofilaments into Lewy body fibrils. Brain Res. 603: 121-124 
Pollanen MS, Bergeron C and WeyerL (1994) Characterization of a shared epitope in cortical Lewy body fibrils and Alzheimer paired helical filaments. Acta Neuropathol. 88: 1-6

Pollanen MS, Dickson DW and Bergeron C (1993b) Pathology and biology of the Lewy body. J. Neuropathol. Exper. Neurol. 52: 183-191

Polymeropoulos MH, Lavedan C, Leroy E, IdeSE, Dehejia A, Dutra A, Pike B, RootH, Rubenstein J, Boyer R, Stenroos ES, Chandrasekharappa S, Athanassiadou A, Papapetropoulos T, Johnson WG, Lazzarini AM, Duvoisin RC, Di lorio G, Golbe $\mathrm{LI}$ and Nussbaum RL (1997) Mutation in the alpha-synuclein gene identififed in families with Parkinson's disease. Science 276: 2045-2047

Poorkaj P, Bird TD, Wijsman E, Nemens E, Garruto RM, Anderson L, Andreadis A, Raskind M and Schellenberg GD (1998) Tau is a candidate gene for frontotemporal dementia. Ann. Neurol. 43: 815-825

Sadoul R (1998) BCL-2 family members in the development and degenerative pathologies of the nervous system. Cell Death Differ. 5: 805-815

Samuel W, Galasko D, Masliah E and Hansen LA (1996) Neocortical Lewy body counts correlate with dementia in the Lewy body variant of Alzheimer's disease. J. Neuropath. Exper. Neurol. 55: 44-52

Schmidt ML, Martin JA, Lee VM-Y and Trojanowski JQ (1996) Convergence of Lewy bodies and neurofibrillary tangles in amygdala neurons of Alzheimer's disease and Lewy body disorders. Acta Neuropathol. 91: 475-481

Schmidt ML, Murray J, Lee VM-Y, Hill WD, Wertkin A and Trojanowski JQ (1991) Epitope map of neurofilament protein domains on cortical and peripheral nervous system Lewy bodies. Am. J. Pathol. 139: 53-65

ShibashiY, Baillie DAM, StClair D and Brookes AJ (1995) High-resolution mapping of SNCA encoding $\alpha$-synuclein, the non-A $\beta$ component of Alzheimer's disease amyloid precursor, to human chromosome 4q21.3-q22 by fluorescence in situ hybridization. Cytogenet. Cell Genet. 71: 54-55

Shibayama-Imazu T, Okahashi I, Omata K, Nakajo S, Ochiai H, Nakai Y, Hama T, Nakamura Y and Nakaya K (1993) Cell and tissue distribution and developmental change of neuron specific $14 \mathrm{kDa}$ protein (phosphoneuroprotein 14). Brain Res. 622: $17-25$

Spillantini MG, Crowther RA, Jakes R, Hasegawa M and Goedert M (1998) $\alpha$ synuclein in filamentous inclusions of Lewy bodies from Parkinson's disease and dementia with Lewy bodies. Proc. Natl. Acad. Sci. USA 95: 6469-6473

Spillantini MG, Divane A and Goedert M (1995) Assignment of human $\alpha$-synuclein (SNCA) and $\beta$-synuclein (SNCB) genes to chromosomes $4 \mathrm{q} 21$ and $5 \mathrm{q} 35$. Genomics 27: 379-381

Spillantini MG, Goedert M, Crowther RA, Murrell JR, Farlow MR and Ghetti B (1997a) Familial multiple system tauopathy with presenile dementia: A disease with abundant neuronal and glial tau filaments. Proc. Natl. Acad. Sci. USA 94: 41134118
Spillantini MG, Schmidt ML, Lee VM-Y, Trojanowski JQ, Jakes R and Goedert M (1997b) $\alpha$-synuclein in Lewy bodies. Nature 388: 839-840

Takeda A, Mallory M, Sundsmo M, Honer W, Hansen L and Masliah E (1998) Abnormal accumulation of NACP/alpha-synuclein in neurodegenerative disorders. Am. J. Pathol. 152: 367-372

Tompkins MM, Basgall EJ, Zamrini E and Hill WD (1997) Apoptotic-like changes in Lewy body-associated disorders and normal aging in substantia nigral neurons. Am. J. Pathol. 150: 119-131

Trojanowski JQ, Galvin JE, Schmidt ML, Tu P-H, Iwatsubo T and Lee VM-Y (1998) Mechanisms of neuron death in neurodegenerative diseases of the elderly: Role of the Lewy body. In Handbook of the Aging Brain, Wang E and Snyder SD (eds). pp. 143-152, (San Diego, Academic Press)

Tu P-h, Galvin JE, Baba M, Giasson B, Tomita T, Leight S, Nakajo S, Iwatsubo T, Trojanowski JQ and Lee VM-Y (1998) Glial cytoplasmic inclusions in white matter oligodendrocytes of multiple system atrophy brains contain insoluble $\alpha$ synuclein. Ann. Neurol. In press

Tu P-H, Gurney ME, Julien J-P, Lee VM-Y and Trojanowski JQ (1997a) Oxidative stress, mutant $S O D I$, and neurofilament pathology in transgenic mouse models of human motor neuron disease. Lab. Invest. 76: 441-456

Tu P-H, Robinson KA, de Snoo F, Eyer J, Peterson A, Lee VM-Y and Trojanowski JQ (1997b) Selective degeneration of Purkinje cells with Lewy body-like inclusions in aged NFHLACZ transgenic mice. J. Neurosci. 17: 1064-1074

Ueda K, Fukushima H, Masliah E, Xia Y, Iwai A, Yoshimoto M, Otero DAC, Kondo J, Ihara Y and Saitoh T (1993) Molecular cloning of a novel component of amyloid in Alzheimer's disease. Proc. Natl. Acad. Sci. USA 90: 11282-11286

Vogel G (1998) Mutations in the tau gene of autosomal dominant frontotemporal dementia with parkinsonism linked to chromosome 17. Science 280: $1524-$ 1525

Wakabayashi K, Matsumoto K, Takayama K, Yoshimoto M and Takahashi H (1997) NACP, a presynaptic protein, immunoreactivity in Lewy bodies in Parkinson's disease. Neurosci. Lett. 239: 45-48

Weinreb PH, Zhen W, Poon AW, Conway KA and Lansbury Jr PT (1996) NACP, a protein implicated in Alzheimer's disease and learning, is natively unfolded. Biochem. 35: 13709-13715

Withers GS, George JM, Banker GA and Clayton DF (1997) Delayed localization of synelfin (synuclein, NACP) to presynaptic terminals in cultured rat hippocampal neurons. Devel. Brain Res. 99: 87-94

Yoshimoto M, Iwai A, Kang D, Otero DA, Xia Y and Saitoh T (1995) NACP, the precursor protein of the non-amyloid $\beta / \mathrm{A} 4$ protein $(\mathrm{A} \beta)$ component of Alzheimer disease amyloid, binds $A \beta$ and stimulates $A \beta$ aggregation. Proc. Natl. Acad. Sci. USA 92: $9141-9145$ 